\title{
Increasing the Efficiency of the Fiscal System - a Parallel between Poland and Romania
}

\author{
Carmen Valentina Rădulescu ${ }^{1, *}$, Dumitru Alexandru Bodislav ${ }^{1}$, and Diana Mihaela \\ Negescu Oancea ${ }^{1}$ \\ ${ }^{1}$ Bucharest University of Economic Studies, Romana Square, no. 6, Bucharest, Romania
}

\begin{abstract}
.
Research background: This paper presents an overview and a fundamental analysis of the fiscal system in Romania and how it should be, also by showing one of the European champions on fiscal efficiency, the Polish system. Although we are talking about the 21 st century, about evolution, economic, financial and fiscal sustainability, the Romanian tax system has been intensely blamed for its inefficiency, outdated procedures and last but not least the excessive bureaucracy. This topic was intensely discussed and debated both by the competent authorities who tried to identify the deepest issues and by the specialized press representing a great interest for both natural and legal taxpayers.

Purpose of the article: The purpose of this paper is to identify the challenges, limits and solutions so that the Romanian tax system can become efficient and implicit, a model to follow for success. The paper shows how the Romanian fiscal system works and how taxes add to the degree of economic growth and what are the limits of actual system.

Methods: The paper evaluates the actual literature, its conceptual limits, the classification and how it should be at technical level.

Findings \& Value added: The research will highlight the harmonization of the Romanian fiscal system with the European Union's one and especially with one of its champions, Poland.
\end{abstract}

Keywords: economic growth; fiscal system; efficiency; emerging markets; tax evasion

JEL Classification: E62; E63

\footnotetext{
* Corresponding author: cv radulescu@yahoo.com
} 


\section{Introduction}

By comparison, the Polish tax system is characterized by high social security contributions for both employers and employees.

Poland has one of the largest tax panels, despite relatively low-income tax rates, which highlights the collection efficiency of this system. This, combined with a relatively high minimum wage and generous early retirement and disability benefit programs, contributes to a low level of employment, especially among low-skilled workers.

The system also relies heavily on consumption taxes, while collecting relatively little income from bases such as environmental externalities, inheritances and, in particular, property [1]. One of the key implications of the tax structure is that the system as a whole is one of the least.

The administration of taxes and duties in Poland is in the hands of two types of authorities: the governmental ones (profit tax, personal income tax, value added tax, excise duties, civil transaction tax) and the local governmental ones (real estate tax, vehicle tax) [2].

The Polish tax administration balances the service and audit functions in all its operations, provides maximum assistance to taxpayers in the correct observance of taxes.

This is evidenced by the specialized offices for large taxpayers (There are special tax offices in Poland ( 20 of them) dedicated specifically to so-called large taxpayers, namely:

- entities that generated an annual income of at least EUR 5 million in the previous year;

- entities directly or indirectly controlled by a non-resident or where a non-resident has at least $5 \%$ of the votes at the shareholders' meeting or at a general meeting;

- entities that, as residents, participate directly or indirectly in the management of companies located abroad or in their control or that have a part of their capital;

- entities that, as residents, simultaneously or indirectly participate in the management of an internal entity and a foreign entity or control or have at the same time a share of the capital of these entities;

- groups of capital taxes, banks and insurance entities;

- branches or representations of foreign entities.

The coordination of audit operations at regional level by the Regional Fiscal Councils (WKS) results in a reduction in the number of audits, their efficient performance and better results [3]. At the same time, the tax administration is redirecting its efforts in a more efficient attempt to deal with tax fraud, which results in the transformation of the shadow economy into an economy that operates in accordance with the law.

This case study examines the comparison between the main indicators of the tax system of Poland and Romania and explores options for improving its efficiency, including the possibilities of broadening existing tax bases, digitization, amending difficult and ambiguous legislation.

\section{Research background: fundamentals of the Polish and Romanian tax systems}

It is important to analyse the impact of government revenues and expenditures on economic growth but also on the efficiency of the fiscal system due to the fact that the state uses fiscal policy as a control tool [4].

In Romania, tax revenues have undergone fluctuating changes. At the peak of the recession in 2009 they registered the lowest share, of 30.3\% of GDP, a value close to this also existed in 2017 as a result of the 2016 increase in tax revenues due to the negative evolution of direct and indirect tax collections. 
In 2018, some fiscal relaxation measures took place: the income tax decreased, as a result of the decrease of the income tax rate by 6 pp starting with January 2018; the level of excise duties for energy products has been reduced.

Compared to Romania, Poland recorded exponentially higher government revenues, also explained by the fact that it has higher tax rates than in Romania. In 2018 and 2019 it registered the largest share of revenues due to the increase in direct taxes.

Government spending in Romania had the largest share in 2010, as a measure taken to get out of the crisis [5]. They also declined due to the need to reduce the budget deficit. Instead, Poland experienced the largest share of expenditures starting with 2018 and continuing with 2019.

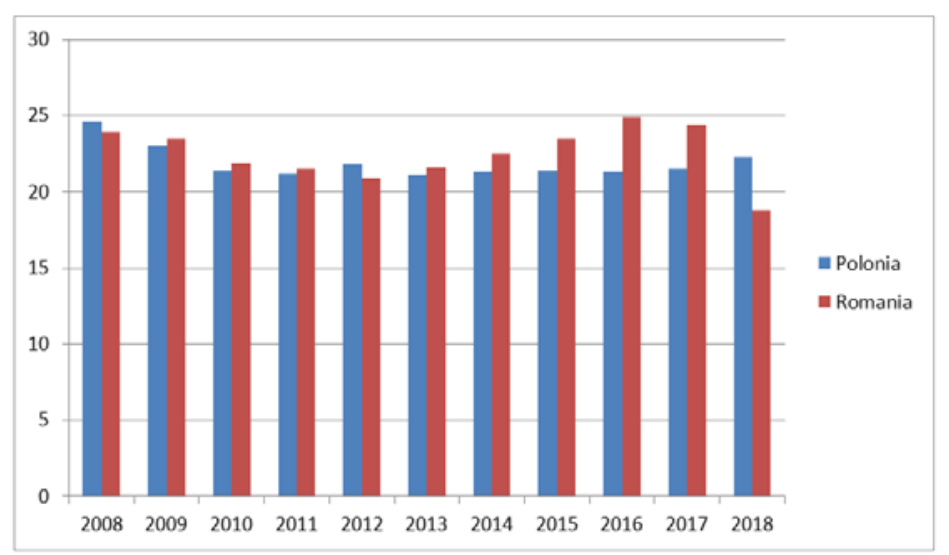

Fig. 1. Evolution of indirect taxes as a percentage of GDP

In the chart above we presented the analysis of the evolution of direct taxes $(\%$ of GDP). We can see that their shares were similar due to similar tax systems, but with a substantial difference from the European Union average [6].

Analyzing the dynamics of the share of direct taxes in total GDP, it can be seen that both Romania and Poland face a problem in terms of tax compliance but also with the tax system mainly (bureaucratic, inefficient, outdated in terms of evolution).

The reasons are also related to the difficulty in reporting and the payment of debts to the state by taxpayers [6].

In this context, we also see an increased stability in the European Union in terms of direct taxes as a share of GDP.

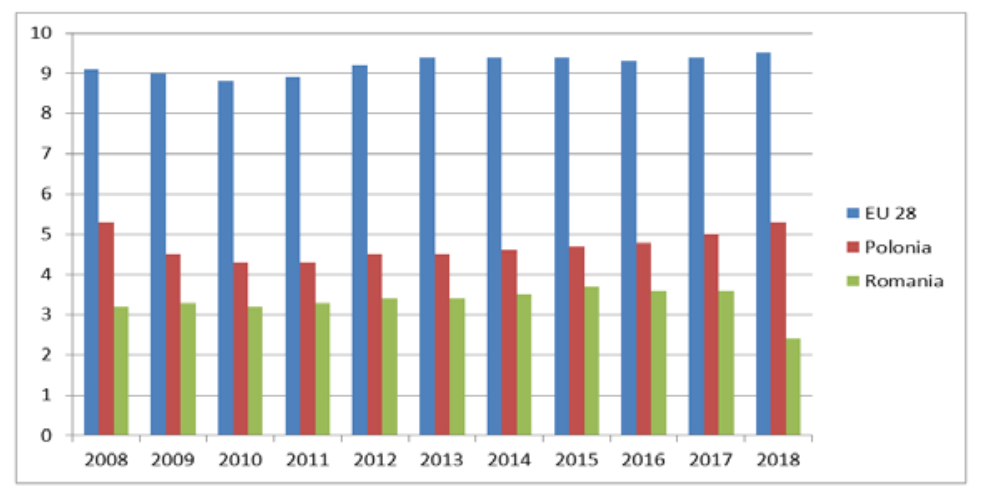

Fig. 2. Evolution of taxes on individual or household incomes, including income as percentage of GDP 
In the graph provided for analysis with the evolution of household income taxes we can see that the lowest values are recorded in Romania, approximately twice lower compared to Poland.

The weights do not show significant changes from year to year, the lowest percentage being registered in Romania in 2018 amid the decrease in the tax rate [7].

In Poland, the largest share of income taxes was first recorded in 2008 amid a very high rate of $40 \%$ at that time.

In 2018, the share of taxes in GDP was identical to that of 2008 as a result of an evolution in the collection system.

However, the average share of household income taxes in the European Union was about 5 percentage points higher than the figures in Poland, and about 6 percentage points compared to the dynamics of shares in Romania.

This substantial difference between the two countries shows us how inefficient the collection system is in the two countries compared to the other Member States of the European Union [8].

The government is not able to verify all the economic results of individuals or households. Indeed, taxpayers may misrepresent income, consumption, wealth or inheritances to avoid or even evade paying taxes. Restrictions on information determine the ability of the government to apply the tax.

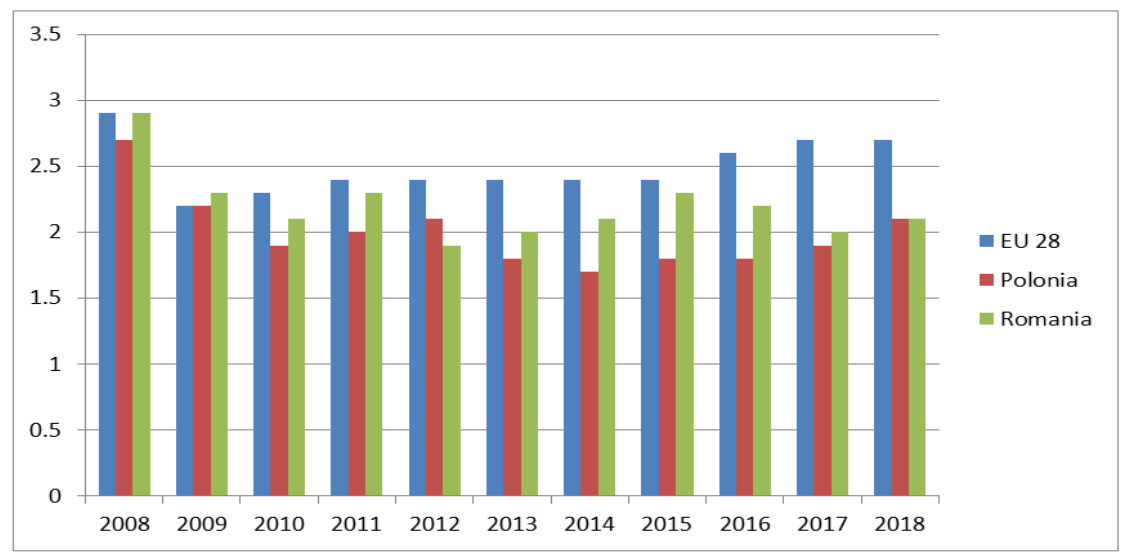

Fig. 3. Evolution of taxes on income and revenue of companies, including obtained income as percentage of GDP

In the chart above we analysed the evolution of the company's income and profit taxes as a percentage of GDP. Unlike household income tax, both Romania and Poland are approaching the European Union average of 2.5 percentage points.

The lowest value of the share was 1.9 percentage points in both Poland and Romania (2017) amid changes in legislation that resulted in a decrease in the level of collection of corporate income and profit tax as a share of GDP.

An amendment to the law that contributed to the change in the share of this tax in GDP in Romania is related to the introduction of a specific tax at the beginning of 2017, resembling a flat tax attributed to entities operating in tourism, food, which paid profit tax [9-10].

In the UK, the HM Revenue and Customs' Connect computer relies on information from a wide range of government and corporate sources, as well as individual fingerprints, to create a profile of each taxpayer's total revenue. Such analytical capacity could even be used to assess the behavioral impact of new fiscal and spending policies. Digital systems play new roles for consumers and third parties in facilitating increased compliance [11]. 
The developing peer-to-peer (P2P) economy, in which a digital platform mediates transactions between individual buyers and sellers, has introduced the organization and formalization of previously informal and perhaps undocumented activities.

Such platforms record large volumes of consumption and revenue data which, if accessible by tax authorities, could play an important role in tax administration [12]. For example, Estonia uses the platform's technology to connect Uber drivers directly to the tax office, adding travel revenue directly to the tax return.

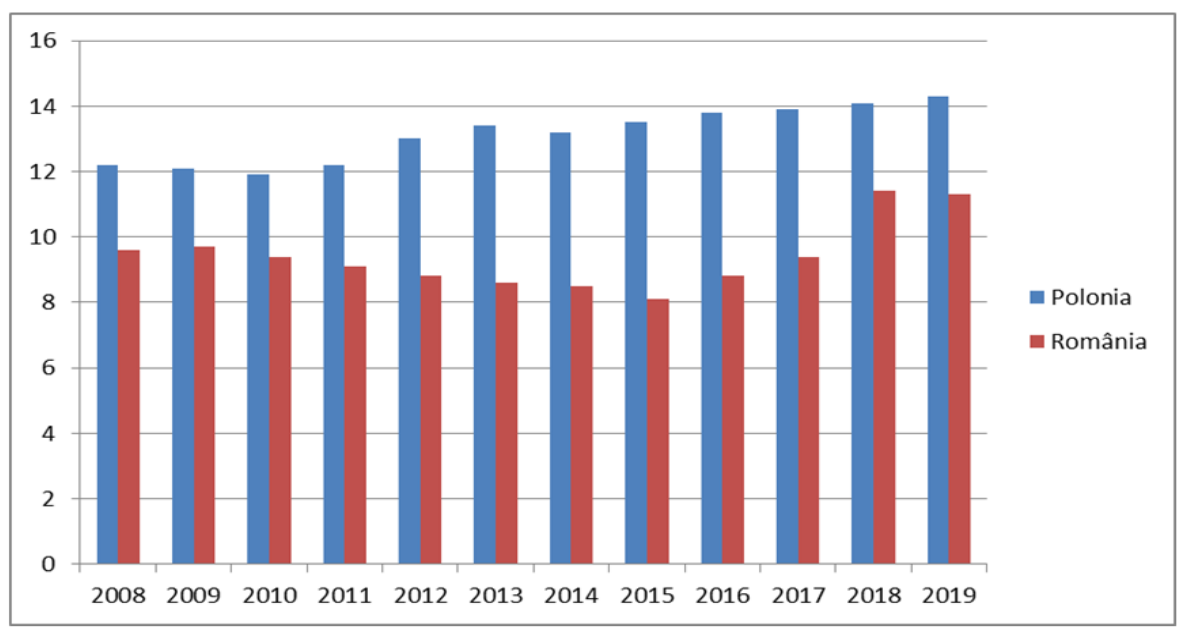

Fig. 4. Evolution of social contributions as percentage of GDP

The previous graph shows the evolution of net social contributions as a share of GDP in Romania and Poland. We can see that in Poland the trend was largely increasing unlike Romania which had mostly decreasing weights until the beginning of the fiscal revolution with subsequent changes in 2017.

It is worth mentioning the similarity of the tax system between the two countries where both the employer and the employee are obliged to contribute to the social insurance system [13]. In Poland, in addition to paying his own share, the employer is obliged to deduct the employee's share of social security contributions and remit them to the social security authorities (ZUS). In both cases, the relevant payments are made monthly. As of April 1, 2015 , the employer pays total contributions between $19.21 \%$ and $22.41 \%$ of the employee's gross salary (the employer's contribution rate includes an accident insurance item that varies depending on the number of insured employees and the business sector). This was also felt in the dynamics of the evolution of the share of social contributions in GDP

For example, the tax authorities in Australia and the United Kingdom now receive realtime reporting of payroll information, and in Brazil and Russia, electronic invoicing systems provide immediate access to company sales data. With the automation of public finance management, several governments can now access high-frequency tax data through information technology systems.

\section{Methods}

The paper evaluates the actual literature, its conceptual limits, the classification and how it should be at technical level. 


\subsection{Direct taxes and total taxes in the relation between Poland and Romania}

Romania had a much lower share of indirect taxes in GDP than Poland. This is certainly due to the VAT rate, which over time has been about 3-4 percentage points higher in Poland than in Romania.

We note that the share of indirect taxation in GDP in Romania was relatively close to that of the European Union average, but in 2010 it recorded the lowest share of taxes due to the unfavourable economic situation at that time. In 2009 Poland recorded the lowest contribution, also being affected by the international economic context of the abovementioned period.

We cannot ignore the fact that in Romania the degree of collection of indirect (but also indirect) taxes is very small, although the number of financial administrations is similar to that of Poland (taking into account of course that this is a country with a double population). This is due both to the lower tax base and to our outdated tax system [14].

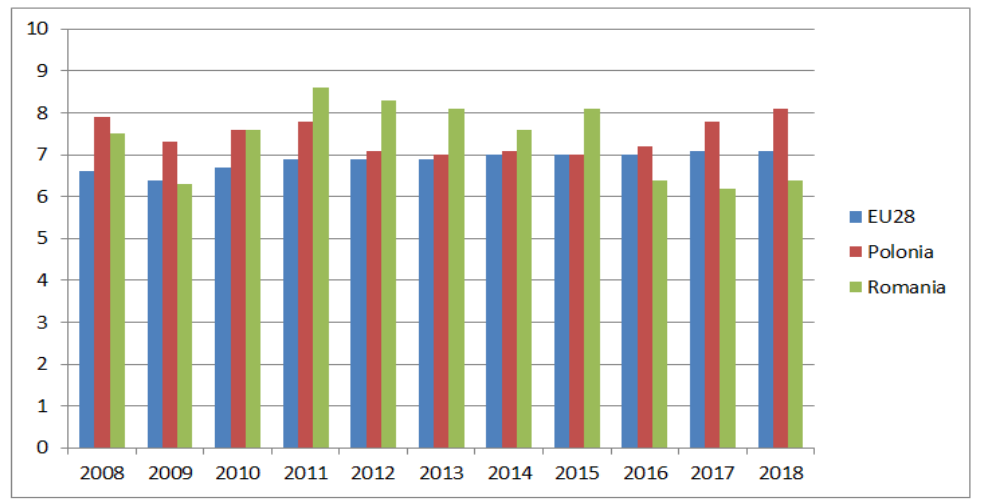

Fig. 5. Evolution of VAT as a percentage of GDP

From the previous graph on the evolution of VAT\% GDP we can notice that Romania has the largest shares, which indicates that this indirect tax is extremely important in a less developed country, Poland's shares being close due to the country's similarities in terms of economically with Romania.

Also, in order to provide a solution to the most efficient collection, I mention the example of Brazil, which offers a role for consumers as auditors, through the Nota Fiscal Paulista program in São Paulo. It uses a digital payment system designed to encourage better application of VAT at the final consumer stage, offering a 30\% tax reduction and monthly lottery prizes to consumers requesting receipts.

The share of total taxes as a ratio of GDP in Romania is four times lower than in Poland. There is also a considerable difference from the European Union average.

If information about individuals were synchronized between public administrations and employers - with digital authentication linked to banking information - changes in individual circumstances automatically captured in these data could immediately trigger coverage and benefit payments without the need for lengthy and possibly stigmatizing procedures to prove eligibility. which involves filling out forms and queuing and thus collecting would be much more efficient [15].

In an ideal world, governments will be able to fully verify all relevant economic results and characteristics of taxpayers at zero cost.

In such a world, individual taxes will be available to redistribute income and increase it. 
Indeed, the government could then condition its fiscal policy on all the characteristics of taxpayers on which it wants to base the redistribution of income: earning capacity, needs, initial endowments, inheritances, luck and so on [16]. Moreover, if the information were perfect, tax avoidance and evasion would not exist.

We are facing a situation in which we are presented with the real dynamics and the substantial differences in deficient collection of our tax system. Poland has maintained its share of total taxes in line with the EU average, demonstrating that although the structure of the tax system is similar to Romania, efficiency makes a difference.

In order to be able to talk about an efficient fiscal system, it is essential to be aware of the need for a digitized fiscal system, a common basis of all existing budget receivables. We also know that a fiscal policy is based on the collection and use of resources to stabilize the business cycle, pursue distribution targets and enable public spending.

Now, all of the above crucially depend on the information and technology available to the government and how it exploits it.

We know that governments stimulate the economy during recessions and reduce it during the period of expansion. They tax to finance social security networks, health and education services, infrastructure, etc. and therefore the design and implementation of fiscal policy is fundamentally shaped by the reliability, timeliness and detail of the information available to the government for the economy. and for its actors [17].

Here we include taxpayers' income and assets, the identity and circumstances of beneficiaries of social programs, the employment status of workers, the size of the output gap, the size and timing of government transactions. By transforming the way governments can collect, process and act on information, digitization is reshaping the formulation and implementation of these policies into a process that has at least begun in Romania.

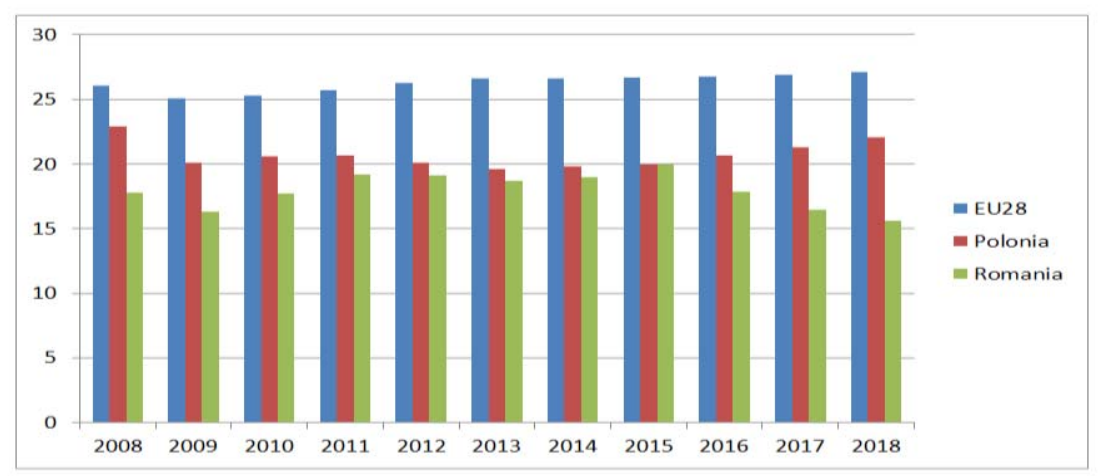

Fig. 6. Evolution of total taxes (without social contribution) as a percentage of GDP

The previous graph shows the percentage evolution of collections in GDP. We can see that the EU has a slightly upward trend, Poland a strong upward trend, but Romania after 2015 is declining rapidly and in the opposite direction to the EU and the comparable standard of Poland.

The trend is downward because after 2016 the collection within the National Agency for Fiscal Administration was inefficient. On June 25, 2019, it published an efficiency plan. Of increasing importance are: changing the procedures of tax administration by reducing the number of forms on the part of legal entities, limiting the periods of submission of corporate tax returns, schematizing declarations for individuals, digitization of tax returns, disciplining the restructuring of outstanding budget receivables and not in lastly, the promise to simplify the payment methods in instalments. 
The Polish VAT rate was increased from $22 \%$ to $23 \%$ in 2011 , amid worsening economic conditions in Europe. Although Poland was one of the few countries to avoid a technical recession, government finances fell sharply.

Poland's ambition to join the single currency Euro has meant increasing the VAT rate to ensure that it meets the 3\% deficit target for euro entry but has not yet reached that target.

Similarly, the VAT rate increased in Romania a year earlier, following attempts to increase government revenues to reduce public debt. An increased VAT rate has the right to increase revenues to the state budget, increases that can be used to finance the payment of the minimum wage. It would also reduce the budget deficit and thus the debt that would have been acquired to finance the minimum wage.

In 2017, there was a fiscal relaxation in Romania in terms of VAT, returning to the share of $19 \%$ of the desire to increase the compliance rate, real estate profits, imports, etc.

In 2018, there was a fiscal relaxation for Romania as a method of streamlining the tax system through a reasoning according to which, a lower tax rate can cause people to work more, reduce the rate of underground economy and thus tax evasion. In Poland, this fiscal easing has been taken as a pro-cyclical measure in the fight against the crisis [17].

We notice that Poland has an almost double income tax rate compared to Romania, but this is also justified by the state services in terms of health, social insurance, defence, etc.

It should be mentioned that although fiscal relaxation measures were taken, this was not enough to be able to talk about an efficiency in collection. A simpler tax system with a limited number of instalments is essential to encourage taxpayer compliance.

This is especially true in economically fragile countries such as Romania. The authorities should first focus on simplifying taxes, procedures and structures.

A technologically advanced tax system adds value to governments by connecting existing information in different parts of the tax system to better detect evasion or avoidance. Better tax enforcement allows governments to get the same lower tax revenues (more efficient) or get more tax revenue with the same taxes.

\section{Results and discussion: value added findings}

We noticed after the study that Romania is a country that compared to Poland is poorly developed in terms of revenues to the state budget, the degree of collection of taxes on profits, income, VAT, social contributions, etc. Taking into account the fact that Poland has a tax system similar to similar tax rates in some places, we concluded which are the most eminent problems that the Romanian tax system has always faced and how we can combat them.

A first step in this context is to step into the era of the technological revolution. Digitization can streamline tax enforcement by gathering increasingly reliable information on taxpayers' economic performance and thus improve offsetting the effectiveness of equity by implementing more complex tax systems to better redistribute revenue. In this sense, digitization allows governments to reduce tax rates in order to collect the same or even higher revenues.

In order to be able to process and disseminate more timely, more easily accessible and transparent information about economic activity, the concept of digital revolution has emerged. Thus, if the state complied, it could accumulate more information, tracking and recording a wide range and volume of transactions and interactions, in other words, a much more efficient tax system. Tax authorities are increasingly gaining access to the large amount of information held by the private sector - such as data on banking transactions and interest income through the use of digital systems, standardized reporting formats and electronic interfaces. 
If governments wanted to adapt to the new era, that of technology would result not only in the economic benefits of better tax application or more efficient tax systems, but also in horizontal equity, with concerns about confidentiality and avoidance. abuses of state power. Indeed, these concerns could be why many of the suggested tax reforms have not been implemented so far, such as age-dependent or gender-based tax programs. Moreover, political and economic constraints can prevent the transition to the second-best border, identified by optimal fiscal analysis.

However, information on the second-best border is important for decision-makers, regardless of whether political restrictions prevent it from reaching that border. Clearly, political distortions are important in real-world policy-making, but the literature does not provide crystallized ideas about how political constraints interact with fiscal distortions.

Digitization can improve tax systems, increase economic efficiency and promote equity in countries with good institutions, well-functioning democracies, the rule of law and strict protection of citizens' privacy.

\section{Conclusion}

The tax system is coordinated through the legislation in force, which is often interpretable. This creates problems in the management of the constitutionality contract and subsequent amendments and additions need to be made. As a solution, I would propose the creation of a special legal basis for local and central tax authorities, respectively.

Another aspect of good functioning is fiscal decentralization. In Romania we can talk about decentralization only from a theoretical point of view, at the legislative level, the concept of financing the responsibilities destined to the local authorities is devoid of substance due to the outdated mechanism. Basically, the money allocated to the state budget is allocated from top to bottom, not the other way around as is natural. This could be possible by amending the law providing for decentralization.

\section{References}

1. Alvesson, M., Willmott, H. (2002). Identity regulation as organization control: producing the appropriate individual. Journal of Management Studies, 39(5), 619-644.

2. Caldwell, N., Roehrich, J., George, G. (2017). Social value creation and relational coordination in public-private collaboration. Journal of Management Studies, 54(6), 906-928.

3. Cohen, B. (2016). The rise of alternative currencies. Journal of Management Studies, 54(5), 739-746.

4. Crossan, M., Byrne, A., Sejits, G., Reno, M., Monzani, L., Gandz, J. (2016). Toward a framework of leader character in organizations. Journal of Management Studies, 54(7), 986-1018.

5. Habersang, S., Kuberling-Jost, J., Reihlen, M., Seckler, C. (2018). A process perspective on organizational failure: qualitative meta-analysis. Journal of Management Studies, 56(1), 19-56.

6. Jianu, I., Dobre, I., Bodislav, D. A., Radulescu, C. V., Burlacu, S. (2019). The implications of institutional specificities on the income inequalities drivers in european union. Economic Computation and Economic Cybernetics Studies and Research, 53(2), $59-76$. 
7. Kohlhase, S., Pierk, J. (2020). The effect of a worldwide tax system on tax management of foreign subsidiaries. Journal of International Business Studies, 51, 1312-1330.

8. Lazar, S. (2010) Sisteme fiscale comparate, Metode si practici international. Bucharest: Wolters Kleiner.

9. Ozalp, H., Cennamo, C., Gawer, A. (2018). Disruption in platform-based ecosystems. Journal of Management Studies, 55(7), 1203-1241.

10. Scherer, A., Palazzo, G. (2011). The new political role of business in a globalized world: a review of a new perspective on CSR and its implications for the firm, governance and democracy. Journal of Management Studies, 48(4), 899-931.

11. Schon, W. (2010), Persons and territories: on international allocation of Taxing rights. British Tax Review, 55, 554-562.

12. Schotter, A., Mudambi, R., Doz, Y., Gaur, A. (2017). Boundary spanning in global organizations. Journal of Management Studies, 54(4), 403-421.

13. Shevchenko, A., Levesque, M., Pagell, M. (2016). Why firms delay reaching true sustainability. Journal of Management Studies, 53(5), 911-935.

14. Tatu L., Serbanescu C., Stefan D., Vasilescu D., Nica A. (2013) Fiscalitatea de la lege la practica. Bucharest: C.H. Beck.

15. Tudose, M. B., Strapuc, C. (2015). The impact of fiscality on the behaviour of taxpayer. Annals of the Constantin Brancusi University of Targu Jiu, Economy Series, 3, 5-9.

16. Vintila, G. (2006). Taxation: tax methods and techniques. Bucharest: Economica Publishing.

17. Waldron, T., Fisher, G., Pfarrer, M. (2016). How social entrepreneurs facilitate the adoption of new industry practices. Journal of Management Studies, 53(5), 821-845. 